Research Article

\title{
The Performance of CRTN Model in a Motorcycle City
}

\author{
Ni Sheng, Zherui Xu, and Min Li \\ Department of Decision Sciences, Macau University of Science and Technology, Macau \\ Correspondence should be addressed to Ni Sheng; nsheng.1@gmail.com
}

Received 5 April 2015; Accepted 29 April 2015

Academic Editor: Valery Sbitnev

Copyright (C) $2015 \mathrm{Ni}$ Sheng et al. This is an open access article distributed under the Creative Commons Attribution License, which permits unrestricted use, distribution, and reproduction in any medium, provided the original work is properly cited.

\begin{abstract}
The Calculation of Road Traffic Noise (CRTN) model is one of the first traffic noise prediction models in the world and has been widely used in many Western countries. However, its performance in a motorcycle city has not been well assessed. This study aims to examine the accuracy of the CRTN model in predicting traffic noise in an Asian city with over half of motor vehicles being motorcycles. The performance of the CRTN model in predicting both roadside and vertical distributions of traffic noise levels is assessed. The results show that the performance of the CRTN model is satisfactory in predicting roadside traffic noise levels, with an $R^{2}$ of 0.832 and a mean difference of $+0.52 \mathrm{~dB}(\mathrm{~A})$ between the measured and predicted values. The performance of the CRTN model is also satisfactory in predicting vertical distribution of traffic noise levels, with an $R^{2}$ of 0.836 and a mean difference of $+0.28 \mathrm{~dB}(\mathrm{~A})$ between the measured and predicted values.
\end{abstract}

\section{Introduction}

Traffic noise affects the health and wellbeing of the people exposed and has drawn more and more attention from the public. Many traffic noise prediction models have been designed for traffic noise assessment in different countries $[1,2]$. In traffic noise modeling, the noise level at a receptor position due to traffic emission source is usually modeled as a function of the traffic conditions (i.e., traffic volume, traffic composition, and traffic speed), road gradient, road surface nature, absorbent ground cover percentage, street configuration, and distance between the traffic emission source and the receptor. The traffic emission source can be considered as point or line source. Traffic noise models assuming point emission source include the United States Federal Highway Administration Traffic Noise Model (FHWA) [3] and the model by the Acoustical Society of Japan (ASJ) [4], while those assuming line emission source include the Calculation of Road Traffic Noise (CRTN) model in the United Kingdom [5] and the RLS-90 model in Germany [6].

The CRTN model is among the first systematic schemes developed to predict noise level due to road traffic. It has been widely used in the United Kingdom, Australia, New Zealand, and Hong Kong. Particularly in the United Kingdom and Hong Kong, CRTN model is the sole instrument for the assessment of road traffic environmental impacts by local authorities. Some researchers have studied the reliability of traffic noise prediction using the CRTN model. The performance of the CRTN model was found to be different under different prevailing conditions [1]. In Australia, Samuels and Saunders [7] reported that the mean overestimation by the CRTN model was $0.7 \mathrm{~dB}(\mathrm{~A})$ for free field conditions and $1.7 \mathrm{~dB}(\mathrm{~A})$ in front of facades. In Hong Kong, Chew and Lim [8] indicated that the error in adopting the CRTN model might increase by more than $10 \mathrm{~dB}(\mathrm{~A})$ when there were buildings on both sides of a road. To et al. [9] found an overestimation of 2 to $6 \mathrm{~dB}(\mathrm{~A})$ by the CRTN model. However, some studies in Hong Kong showed that the accuracy of the CRTN model was satisfactory and the predicted results using the CRTN model correlated well with the measured results with an $R^{2}$ of 0.7742 to 0.9331 and a mean difference of $+0.4 \mathrm{~dB}(\mathrm{~A})$ to $+2.0 \mathrm{~dB}(\mathrm{~A})[10-14]$.

This study aims to assess the validity of the CRTN model in a motorcycle city. Motorcycle is not a major concern in traffic noise modelling in Western countries, as the amount of motorcycles is not significant in general. In the CRTN model, motorcycles are simply treated as passenger cars. However, traffic conditions in the east and west are different. In many Asian urban areas such as Taiwan, India, Vietnam, Thailand, and Macau, motorcycles could occupy over half of the traffic 
on a number of roads [15-17]. Therefore, it is necessary to study whether the CRTN model is reliable and suitable for predicting traffic noise in a city with high incidence of motorcycle use. In this paper, Macao is selected as a case city because it has a high traffic density of 541 vehicles $/ \mathrm{km}$ and $52.4 \%$ of licensed motor vehicles are motorcycles [18].

\section{Materials and Methods}

2.1. CRTN Model. The calculation of the CRTN model assumes typical traffic and noise propagation conditions that are consistent with moderately adverse wind velocities and directions during the specified periods. At a reception point with a reference distance of $10 \mathrm{~m}$ away from the nearside carriageway edge, the basic hourly noise level can be calculated by $[5,19]$

$$
L_{\text {Basic }}=42.2+10 \log _{10} q,
$$

where $q$ is the hourly traffic volume of all heavy and light vehicles and $L_{\text {Basic }}$ is the basic hourly noise level. Here it is assumed that the source line is $0.5 \mathrm{~m}$ above the carriageway and $3.5 \mathrm{~m}$ from the nearside carriageway edge; see Figure 1.

The calculation of the basic noise level by (1) assumes that the basic traffic speed on the road is $75 \mathrm{~km} / \mathrm{h}$, the percentage of heavy vehicles is $0 \%$, and the road gradient is $0 \%$. The adjustment for actual mean traffic speed and percentage of heavy vehicles $\Delta L_{\mathrm{PV}}$ can be applied by

$$
\begin{aligned}
\Delta L_{\mathrm{PV}}= & 33 \log _{10}\left(V+40+\frac{500}{V}\right)+10 \log _{10}\left(1+\frac{5 P}{V}\right) \\
& -68.8
\end{aligned}
$$

where $V$ is the mean traffic speed that depends on road classification as specified by CoRTN model and $P$ is the percentage of heavy vehicles given by

$$
P=\frac{100 f}{q},
$$

where $f$ is the hourly flow of heavy vehicles.

The traffic speed $V$ in (2) depends on the road gradient. For a nonzero road gradient, traffic speed will be adjusted by

$$
\Delta V=\left[0.73+\left(2.3-\frac{1.15 P}{100}\right) \frac{P}{100}\right] G
$$

where $G$ is the road gradient. As a result, $\Delta L_{\mathrm{PV}}$ in (2) can be expressed as

$$
\begin{aligned}
\Delta L_{\mathrm{PV}}= & 33 \log _{10}\left(V+\Delta V+40+\frac{500}{(V+\Delta V)}\right) \\
& +10 \log _{10}\left(1+\frac{5 P}{(V+\Delta V)}\right)-68.8 .
\end{aligned}
$$

The adjustment of basic noise level for road gradient $\Delta L_{G}$ is given by

$$
\Delta L_{G}=0.3 G
$$

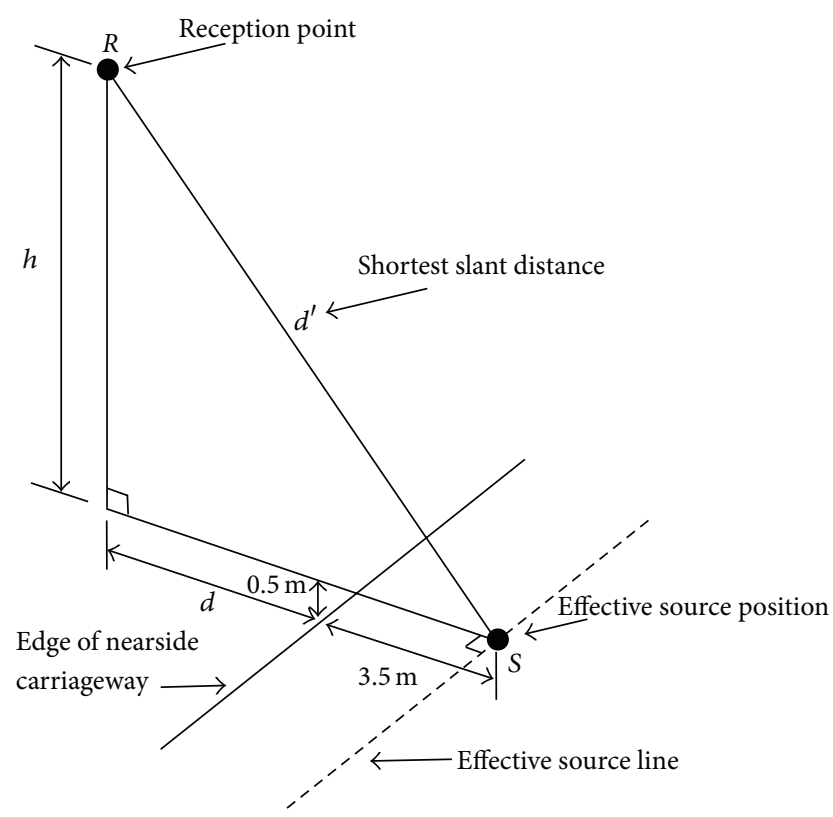

FIGURE 1: An illustration of the positions of source and reception point.

Subsequently, the corrections to the basic noise level are added to take into account the effects of distance from the source line, the nature of the ground surface, screening from any intervening obstacles, and reflections from buildings and façades. The distance correction can be calculated by

$$
\Delta L_{D}=-10 \log _{10}\left(\frac{d^{\prime}}{13.5}\right)
$$

where $d^{\prime}$ is the shortest slant distance from the source position given by $d^{\prime}=\sqrt{(d+3.5)^{2}+h^{2}}, d$ is the shortest horizontal distance between the nearside carriageway edge and the reception point, and $h$ is the vertical distance between the source position and the reception point; see Figure 1. The shortest horizontal distance $d$ is assumed to be not less than $4 \mathrm{~m}$.

The correction for ground cover can be calculated by

$$
\begin{aligned}
& \Delta L_{\mathrm{GC}} \\
& = \begin{cases}5.2 I \log _{10}\left(\frac{3}{(d+3.5)}\right) & \text { for } H<0.75 \\
5.2 I \log _{10}\left(\frac{(6 H-1.5)}{(d+3.5)}\right) & \text { for } 0.75 \leq H<\frac{(d+5)}{6} \\
0 & \text { for } H \geq \frac{(d+5)}{6},\end{cases}
\end{aligned}
$$

where $H$ and $I$ are, respectively, the mean height and the proportion of absorbing ground between the edge of 
the nearside carriageway and the segment boundaries leading to the reception point.

In the CoRTN method, the reflection correction is calculated by

$$
\Delta L_{F}=2.5+1.5\left(\frac{\theta^{\prime}}{\theta}\right) \text {, }
$$

where the correction of $2.5 \mathrm{~dB}(\mathrm{~A})$ is to take into account the reflection of noise from façade adjacent to the reception point (or on the nearside of the reception point), $1.5\left(\theta^{\prime} / \theta\right) \mathrm{dB}(\mathrm{A})$ is the correction for reflection from opposite façade facing the reception point, $\theta^{\prime}$ is the sum of the angles subtended by all the reflecting façades on the opposite side of the road facing the reception point, and $\theta$ is the total angle of view at the reception point.

2.2. Data Collection. In this study, Macao Peninsula is selected as the study area. Macao Peninsula is the administrative, economic, transportation, and cultural center of Macao. It has a small area of $9.3 \mathrm{~km}^{2}$ and a mixed landuse development (i.e., a mixture of residential, commercial, industrial, or other land uses in a building or set of buildings) [20]. Fifty-four on-site measurements were conducted during the morning and evening peak hours between October and December 2013. Of the 54 measurements, 31 were conducted at 31 roadsides representing different road types and traffic characteristics (see Figure 2) while 23 were conducted at different floor levels of a selected secondary school building (see Figure 3).

For each measurement, data collected included traffic noise level, traffic composition, traffic volume, vehicle speed, and road characteristics. The traffic noise measurements of sound pressure level were conducted by using noise statistics analyzer HS6298A. For a roadside measurement, the receiving point was set back at a distance of $0.2 \mathrm{~m}$ from the curb on the pedestrian sidewalk at a height of $1.55 \mathrm{~m}$ from the local ground level. For the measurement inside the building, the receiving point was set close to the window of each floor; see Figure 3. It should be noted that the measuring point was selected to be far from road intersections and other possible noise sources such as traffic control signals, noisy markets, and construction sites.

In each traffic noise measurement, traffic characteristics including traffic composition, traffic volume, and speed of vehicles on the road were recorded simultaneously for noise prediction purposes. In the CRTN model, traffic composition is generally divided into light vehicles $(<1525 \mathrm{~kg}$ unladen weight) and heavy vehicles ( $>1525 \mathrm{~kg}$ unladen weight). In this study, light vehicles included private cars, taxis, small vans, and motorcycles, while heavy vehicles included trucks and buses. The traffic volume for each type of vehicles on the road was counted in 20-minute interval. The speed of each type of vehicles was estimated and the average speed of vehicles was calculated. In addition to the traffic data, geometrical dimensions of the road section and the site layout were also documented.

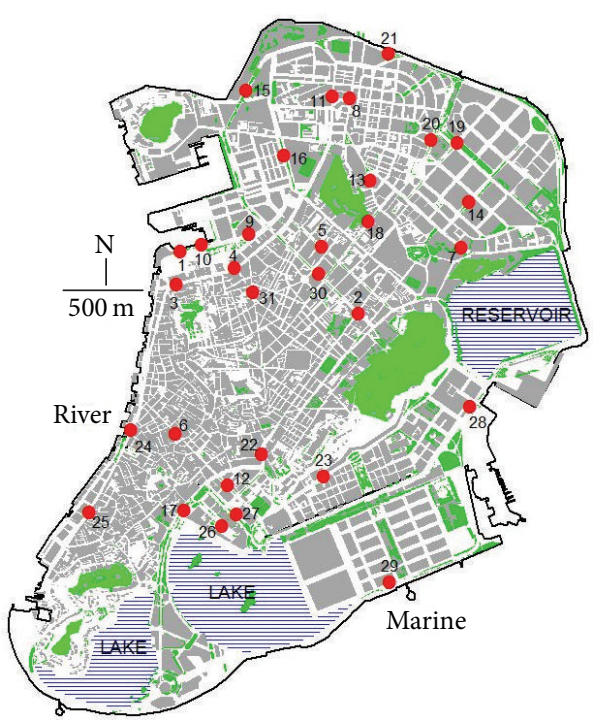

FIgURE 2: Thirty-one sites for 31 roadside measurements in Macao Peninsula.

\section{Results and Discussion}

3.1. Prediction and Measurement at Roadsides. The measured traffic noise levels at 31 roadsides are shown in Table 1. It was found that the average traffic noise at the 31 roadsides was $77.16 \mathrm{~dB}(\mathrm{~A})$. All traffic noise levels exceeded $70 \mathrm{~dB}(\mathrm{~A})$. It should be noted that, until now, there has been no road traffic noise standard in Macao. This study referred to the Hong Kong Planning Standards and Guidelines in which a standard of $70 \mathrm{~dB}(\mathrm{~A})\left(L_{A 10}\right.$ in 1 hour) has been set for road traffic noise. The results show that about $80 \%$ of traffic noise levels at the roadsides investigated in this study were above the benchmark of $70 \mathrm{~dB}(\mathrm{~A})$ by $5 \mathrm{~dB}(\mathrm{~A})$, which confirms that the Macao Peninsula has fallen into a situation of serious traffic noise pollution [21]. In Macao, the total number of licensed motor vehicles is 227,937 , in which $52.4 \%$ are motorcycles and $44.6 \%$ are light vehicles [18]. On the 31 road sections investigated in this study, the average percentage of motorcycles in light vehicles was 57.9\%. In particular, 9 out of the 31 road sections had the percentages of motorcycles in light vehicles higher than $70 \%$.

The validation of CRTN model was carried out by comparing the on-site traffic noise measurements and the corresponding CRTN predictions. As shown in Table 1, the deviations between the measured and predicted traffic noise levels at 31 roadsides did not exceed $3 \mathrm{~dB}(\mathrm{~A})$. The maximum deviation was an overestimation of $2.96 \mathrm{~dB}(\mathrm{~A})$ at Road 22 (Rua do Campo). Deviations of less than $1 \mathrm{~dB}(\mathrm{~A})$ were found at 21 out of the 31 roadsides. The CRTN model overestimated traffic noise level by $0.52 \mathrm{~dB}(\mathrm{~A})$ on average. Figure 4 shows the scatter plot drawn between the measured and predicted values of traffic noise. Using the regression analysis, it was found that the predicted traffic noise levels by the CRTN model correlated well with the measured values with an $R^{2}$ of 0.832 . 

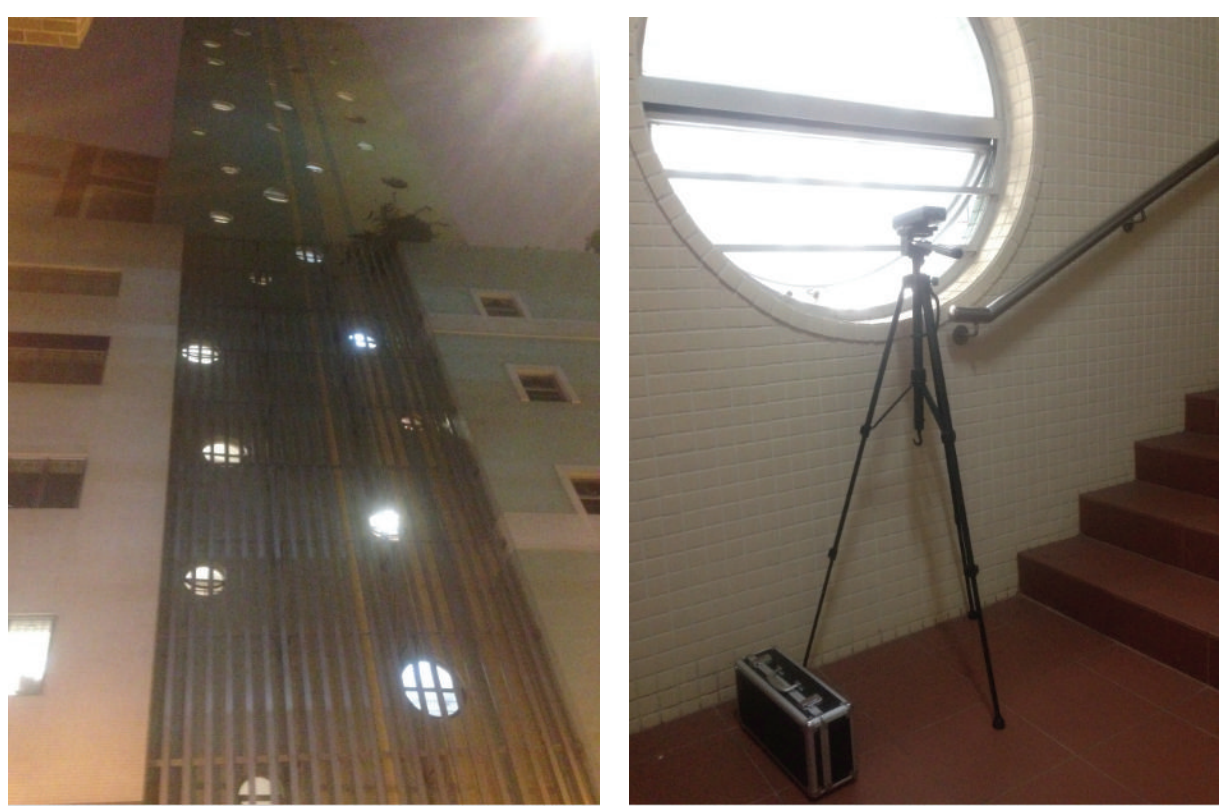

FIGURE 3: Twenty-three measurements in a selected secondary school building.

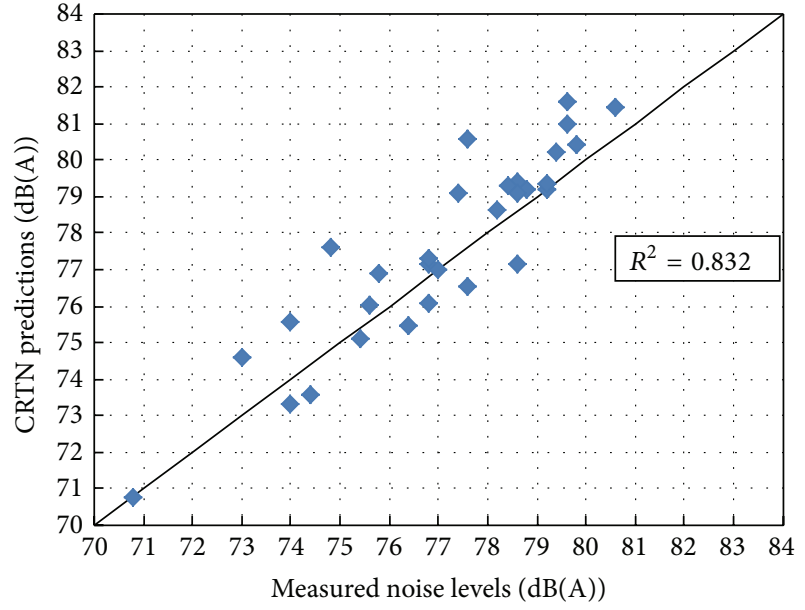

FIGURE 4: Predicted traffic noise levels against measured values at 31 roadsides.

3.2. Prediction and Measurement at Different Floor Levels in a Building. The measured traffic noise levels at 23 different floor levels of a selected secondary school building are shown in Table 2 and Figure 5. It was found that the measured $L_{A 10}$ exceeded the benchmark of $70 \mathrm{~dB}(\mathrm{~A})$ at a height lower than about $21.9 \mathrm{~m}$. The maximum $L_{A 10}$ was $74.2 \mathrm{~dB}(\mathrm{~A})$ which occurred at the first receptor point with the lowest height of $3.3 \mathrm{~m}$ above sound source. While the minimum $L_{A 10}$ was $65.4 \mathrm{~dB}(\mathrm{~A})$ which occurred at the highest receptor point of $43.8 \mathrm{~m}$ above sound source, the measured $L_{A 10}$ 's generally decrease with the increase of building height.

The CRTN predictions at 23 floor levels are also shown in Table 2 and Figure 5 for comparison. It can be observed that

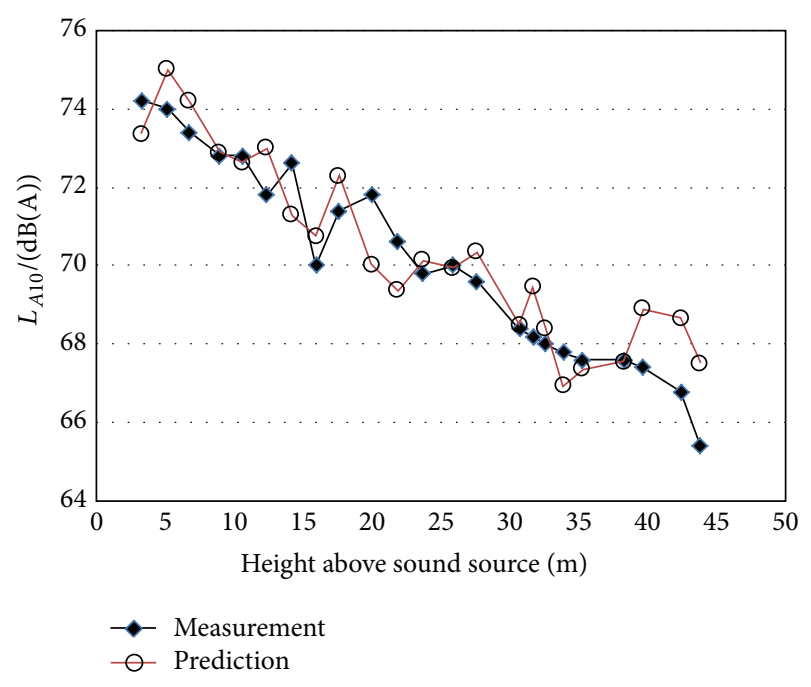

FIGURE 5: Predicted and measured $L_{A 10}$ against height of receptor point.

the differences between the measured and predicted traffic noise levels were in the range of $-1.77 \mathrm{~dB}(\mathrm{~A})$ to $+2.12 \mathrm{~dB}(\mathrm{~A})$. The mean difference was $+0.28 \mathrm{~dB}(\mathrm{~A})$. The deviations at 19 receptors did not exceed $1.5 \mathrm{~dB}(\mathrm{~A})$. Deviations of more than $1.5 \mathrm{~dB}(\mathrm{~A})$ were found at the three highest receptors (with a height of more than $39.7 \mathrm{~m}$ ). This is similar to other research results [12-14], which indicated that the CRTN model tended to overestimate $L_{A 10}$ at higher floor levels of the building. Figure 6 shows the scatter plot drawn between the measured and predicted traffic noise levels at different floor levels. It was found that the CRTN predictions correlated well with the measured values with an $R^{2}$ of 0.836 . 
TABLE 1: Measured and predicted traffic noise levels at 31 roadsides.

\begin{tabular}{|c|c|c|c|c|}
\hline & & Measurement & $\begin{array}{c}\text { CRTN } \\
\text { prediction }\end{array}$ & Differences \\
\hline 1 & Av. Marginal do Lam Mao-a & 78.60 & 77.13 & -1.47 \\
\hline 2 & Av. de Horta e Costa-a & 76.80 & 76.09 & -0.71 \\
\hline 3 & Av. do Almirante Lacerda-a & 78.80 & 79.17 & 0.37 \\
\hline 4 & Estrada do Repouso & 76.80 & 77.14 & 0.34 \\
\hline 5 & Av. do Ouvidor Arriaga & 77.60 & 76.54 & -1.06 \\
\hline 6 & Av. de Almeida Ribeiro & 79.20 & 79.34 & 0.14 \\
\hline 7 & Av. de Venceslau de Morais & 79.20 & 79.18 & -0.02 \\
\hline 8 & Istmo Ferreira do Amaral & 77.40 & 79.10 & 1.70 \\
\hline 9 & Av. Marginal do Lam Mao-b & 74.40 & 73.57 & -0.83 \\
\hline 10 & Av. Marginal do Lam Mao-c & 77.00 & 77.01 & 0.01 \\
\hline 11 & Av. de Artur Tamagnini Barbosa & 78.60 & 79.42 & 0.82 \\
\hline 12 & Av. do Infante D. Henrique & 78.20 & 78.65 & 0.45 \\
\hline 13 & Estrada da Areia Preta & 79.40 & 80.24 & 0.84 \\
\hline 14 & Av. do Nordeste & 75.40 & 75.13 & -0.27 \\
\hline 15 & Av. do Comendador Ho Yin & 76.40 & 75.49 & -0.91 \\
\hline 16 & Av. do General Castelo Branco & 76.80 & 77.32 & 0.52 \\
\hline 17 & Av. da Praia Grande & 74.80 & 77.63 & 2.83 \\
\hline 18 & Rua de Francisco Xavier Pereira & 74.00 & 73.31 & -0.69 \\
\hline 19 & Av. 1 de Maio & 75.80 & 76.92 & 1.12 \\
\hline 20 & Av. Leste do Hipódromo & 73.00 & 74.62 & 1.62 \\
\hline 21 & Av. Norte do Hipódromo & 79.60 & 81.59 & 1.99 \\
\hline 22 & Rua do Campo & 77.60 & 80.56 & 2.96 \\
\hline 23 & Av. do Dr. Rodrigo Rodrigues & 79.60 & 81.00 & 1.40 \\
\hline 24 & Rua das Lorchas & 78.40 & 79.32 & 0.92 \\
\hline 25 & Rua do Almirante Sérgio & 79.20 & 79.34 & 0.14 \\
\hline 26 & Av. Comercial de Macau & 70.80 & 70.74 & -0.06 \\
\hline 27 & Av. Doutor Mário Soares & 74.00 & 75.55 & 1.55 \\
\hline 28 & Av. da Amizade & 80.60 & 81.43 & 0.83 \\
\hline 29 & Av. Dr. Sun Yat-Sen & 79.80 & 80.43 & 0.63 \\
\hline 30 & Av. de Horta e Costa-b & 75.60 & 76.05 & 0.45 \\
\hline 31 & Av. do Almirante Lacerda-b & 78.60 & 79.11 & 0.51 \\
\hline
\end{tabular}

\section{Conclusion}

This study has examined whether the Calculation of Road Traffic Noise (CRTN) model is reliable and suitable for predicting traffic noise in a city with high incidence of motorcycle use. Thirty-one on-site measurements were conducted at roadsides which represented different road types and traffic characteristics in an Asian city with over half of licensed motor vehicles being motorcycles. The differences between the measurements and the corresponding CRTN predictions at 31 roadsides were in the range of $-1.47 \mathrm{~dB}(\mathrm{~A})$ to $+2.96 \mathrm{~dB}(\mathrm{~A})$, and the mean difference was $+0.52 \mathrm{~dB}(\mathrm{~A})$. The CRTN predictions of roadside traffic noise levels correlated well with the measured values with an $R^{2}$ of 0.832 .

The performance of the CRTN model in predicting the vertical distribution of traffic noise level in a motorcycle city was also evaluated by comparing the CRTN predictions and the measurements at 23 different floor levels of a selected secondary school building. The results show that the differences between the measured and predicted traffic noise levels were in the range of $-1.77 \mathrm{~dB}(\mathrm{~A})$ to $+2.12 \mathrm{~dB}(\mathrm{~A})$, and the mean difference was $+0.28 \mathrm{~dB}(\mathrm{~A})$. The $\mathrm{CRTN}$ predictions of vertical distribution of traffic noise levels correlated well with the measured values with an $R^{2}$ of 0.836 .

The present study suggests that the CRTN model is a reliable model in predicting both roadside and vertical distributions of traffic noise levels for a city with high rates of motorcycle use. Nevertheless, the accuracy of the CRTN model for a motorcycle city could be further improved in the future by considering the effects of the percentage of motorcycles in light vehicles. 
TABLE 2: Measured and predicted traffic noise levels at different floor levels.

\begin{tabular}{|c|c|c|c|c|}
\hline Receptor & $\begin{array}{l}\text { Height above } \\
\text { sound source } \\
(\mathrm{m})\end{array}$ & $\begin{array}{c}\text { Measurement } \\
\mathrm{dB}(\mathrm{A})\end{array}$ & $\begin{array}{c}\text { CRTN } \\
\text { prediction } \\
\mathrm{dB}(\mathrm{A}) \\
\end{array}$ & $\begin{array}{l}\text { Differences } \\
\mathrm{dB}(\mathrm{A})\end{array}$ \\
\hline 1 & 3.3 & 74.20 & 73.35 & -0.85 \\
\hline 2 & 5.2 & 74.00 & 74.99 & 0.99 \\
\hline 3 & 6.8 & 73.40 & 74.19 & 0.79 \\
\hline 4 & 9.0 & 72.80 & 72.89 & 0.09 \\
\hline 5 & 10.6 & 72.80 & 72.62 & -0.18 \\
\hline 6 & 12.4 & 71.80 & 72.98 & 1.18 \\
\hline 7 & 14.2 & 72.60 & 71.30 & -1.30 \\
\hline 8 & 16.0 & 70.00 & 70.75 & 0.75 \\
\hline 9 & 17.6 & 71.40 & 72.28 & 0.88 \\
\hline 10 & 20.0 & 71.80 & 70.03 & -1.77 \\
\hline 11 & 21.9 & 70.60 & 69.36 & -1.24 \\
\hline 12 & 23.7 & 69.80 & 70.14 & 0.34 \\
\hline 13 & 25.9 & 70.00 & 69.94 & -0.06 \\
\hline 14 & 27.6 & 69.60 & 70.35 & 0.75 \\
\hline 15 & 30.7 & 68.40 & 68.49 & 0.09 \\
\hline 16 & 31.7 & 68.20 & 69.47 & 1.27 \\
\hline 17 & 32.6 & 68.00 & 68.39 & 0.39 \\
\hline 18 & 33.9 & 67.80 & 66.94 & -0.86 \\
\hline 19 & 35.3 & 67.60 & 67.38 & -0.22 \\
\hline 20 & 38.3 & 67.60 & 67.56 & -0.04 \\
\hline 21 & 39.7 & 67.40 & 68.91 & 1.51 \\
\hline 22 & 42.4 & 66.80 & 68.67 & 1.87 \\
\hline 23 & 43.8 & 65.40 & 67.52 & 2.12 \\
\hline
\end{tabular}

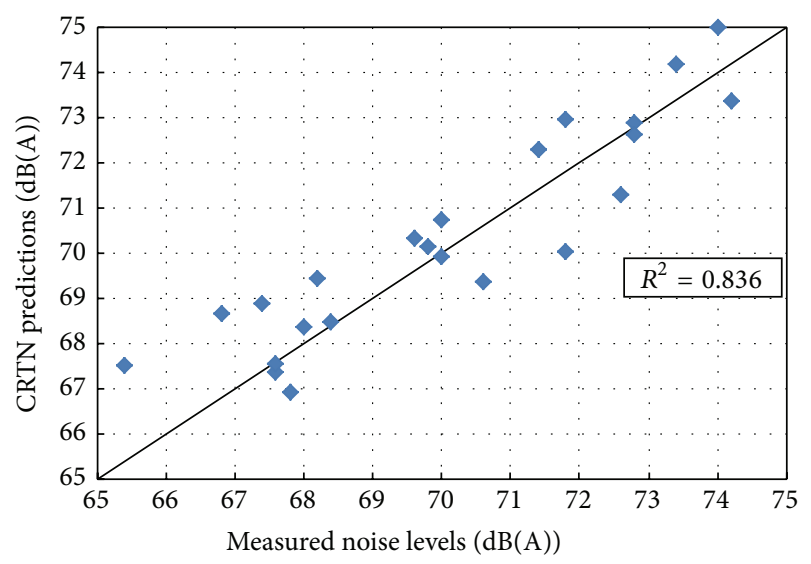

Figure 6: Predicted and measured $L_{A 10}$ at different floor levels in a building.

\section{Conflict of Interests}

The authors declare that there is no conflict of interests regarding the publication of this paper.

\section{Acknowledgments}

This study was supported by the Science and Technology Development Fund (FDCT) in Macao (Project no. 120/2012/A) and the Faculty Research Grant (0430) in Macao University of Science and Technology.

\section{References}

[1] C. M. Steele, "A critical review of some traffic noise prediction models," Applied Acoustics, vol. 62, no. 3, pp. 271-287, 2001.

[2] N. Garg and S. Maji, "A critical review of principal traffic noise models: strategies and implications," Environmental Impact Assessment Review, vol. 46, pp. 68-81, 2014.

[3] G. S. Anderson, C. W. Menge, C. F. Rossano et al., "FHWA traffic noise model, version 1.0: introduction to its capacities and screen components," The Wall Street Journal, vol. 22, pp. 14-17, 1996.

[4] H. Tachibana and M. Sasaki, "ASJ prediction methods of road traffic noise," in Proceedings of the Inter-Noise, pp. 283-288, 1994.

[5] Department of Transport. Welsh Office, Calculation of Road Traffic Noise, HMSO, London, UK, 1988.

[6] Bundesminister für Verkehr, Richtlinien für den Lärmschutz an Straßen RLS-90, Bundesministerium für Verkehr, Abteilung Straßenbau, 1990.

[7] S. E. Samuels and R. E. Saunders, "The Australian performance of the UK DoE traffic noise prediction method," in Proceedings of the 11th Australian Road Research Board Conference, pp. 3044, ARRB Group, August 1982.

[8] C. H. Chew and K. B. Lim, "Facade effects on the traffic noise from the expressway," Applied Acoustics, vol. 41, no. 1, pp. 47-62, 1994.

[9] W. M. To, R. C. W. Ip, G. C. K. Lam, and C. T. H. Yau, "A multiple regression model for urban traffic noise in Hong Kong," Journal of the Acoustical Society of America, vol. 112, no. 2, pp. 551-556, 2002.

[10] W. H. K. Lam and M. L. Tam, "Reliability analysis of traffic noise estimates in Hong Kong," Transportation Research Part D: Transport and Environment, vol. 3, no. 4, pp. 239-248, 1998.

[11] K. M. Li, W. K. Lui, K. K. Lau, and K. S. Chan, "A simple formula for evaluating the acoustic effect of balconies in protecting dwellings against road traffic noise," Applied Acoustics, vol. 64, no. 7, pp. 633-653, 2003.

[12] B. K. H. Leung and C. M. Mak, "Is the CRTN method reliable and accurate for Traffic Noise prediction in Hong Kong?" The Hong Kong Institution of Engineers Transactions, vol. 15, no. 2, pp. 17-23, 2008.

[13] C. Mak, W. Leung, and G. Jiang, "Measurement and prediction of road traffic noise at different building floor levels in Hong Kong," Building Services Engineering Research \& Technology, vol. 31, no. 2, pp. 131-139, 2010.

[14] C. M. Mak and W. S. Leung, "Traffic Noise measurement and prediction of the barrier effect on traffic noise at different building levels," Environmental Engineering and Management Journal, vol. 12, no. 3, pp. 449-456, 2013.

[15] H. Y. T. Phan, T. Yano, T. Sato, and T. Nishimura, "Characteristics of road traffic noise in Hanoi and Ho Chi Minh City, Vietnam," Applied Acoustics, vol. 71, no. 5, pp. 479-485, 2010.

[16] T.-Y. Chang, C.-S. Liu, B.-Y. Bao, S.-F. Li, T.-I. Chen, and Y.-J. Lin, "Characterization of road traffic noise exposure and 
prevalence of hypertension in central Taiwan," Science of the Total Environment, vol. 409, no. 6, pp. 1053-1057, 2011.

[17] U. W. Tang and Z. S. Wang, "Influences of urban forms on traffic-induced noise and air pollution: results from a modelling system," Environmental Modelling and Software, vol. 22, no. 12, pp. 1750-1764, 2007.

[18] DSEC, Yearbook of Statistics 2013, Statistics and Census Service, Macao SAR Government, 2013.

[19] M. E. Delany, D. G. Harland, R. A. Hood, and W. E. Scholes, "The prediction of noise levels $\mathrm{L}_{10}$ due to road traffic," Journal of Sound and Vibration, vol. 48, no. 3, pp. 305-325, 1976.

[20] U. W. Tang and N. Sheng, "Macao," Cities, vol. 26, no. 4, pp. 220231, 2009.

[21] N. Sheng and U. W. Tang, "Spatial analysis of urban form and pedestrian exposure to traffic noise," International Journal of Environmental Research and Public Health, vol. 8, no. 6, pp. 1977-1990, 2011. 


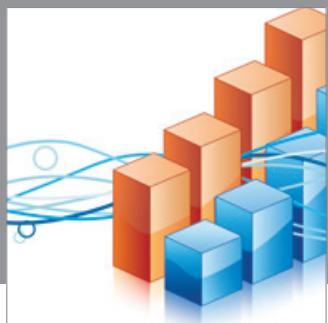

Advances in

Operations Research

mansans

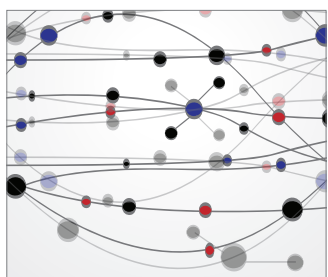

The Scientific World Journal
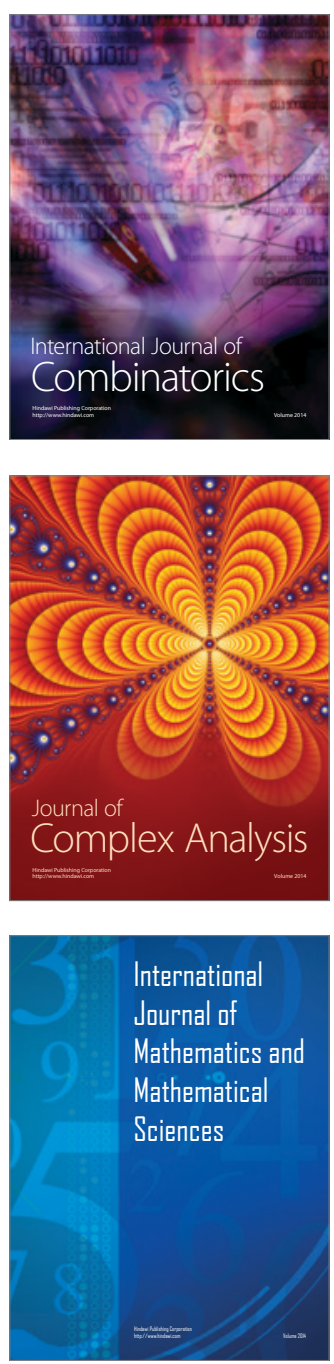
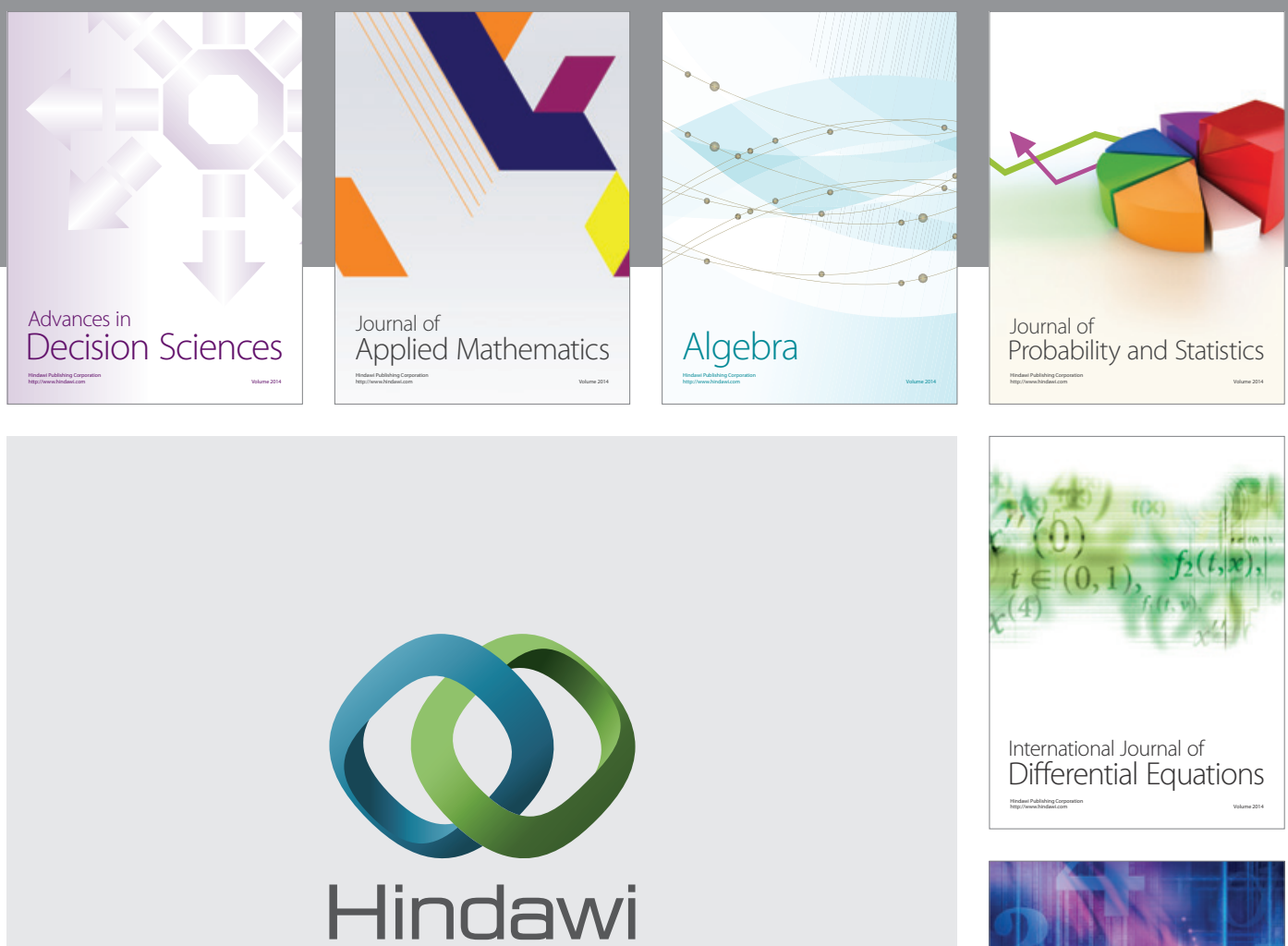

Submit your manuscripts at http://www.hindawi.com
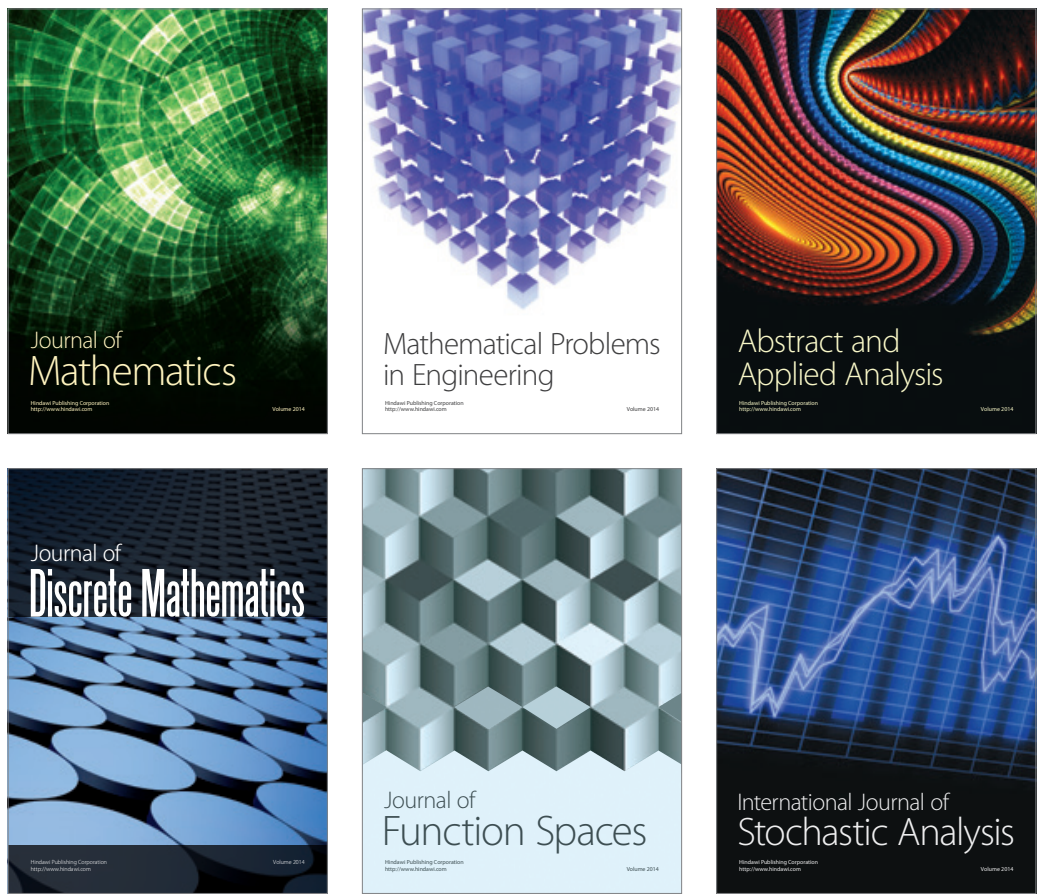

Journal of

Function Spaces

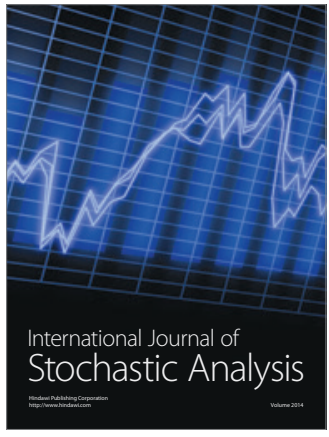

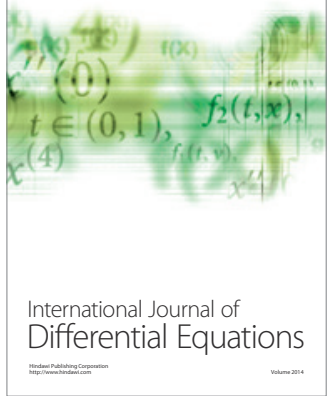
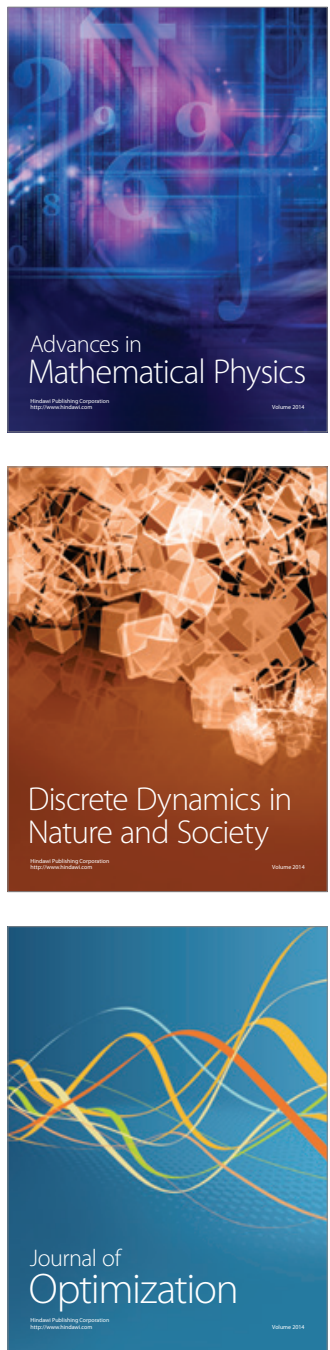